\title{
IAMJ
}

INTERNATIONAL

AYURVEDIC

MEDICAL JOURNAL

ISSN: 23205091

Impact Factor: 5.34

\section{A COMPARATIVE CLINICAL STUDY OF SHATAVARIGOPAKANYADI KASHAYA AND VASADI KASHAYA IN ASRIGDARA}

\author{
$\underline{\text { Priyanka Prem }}^{1}$, Kavitha B.K ${ }^{2}$
}

${ }^{1} 3^{\text {rd }}$ year P.G. Scholar, Dept. of Prasooti Tantra Evum Stree Roga, Alva's Ayurveda Medical

College, Moodbidri, Karnataka, India

${ }^{2}$ Associate Professor, Dept. of Prasooti Tantra Evum Stree Roga, Alva's Ayurveda Medical College, Moodbidri, Karnataka, India

Corresponding Author: priyankavprem@gmail.com

\section{https://doi.org/10.46607/iamj1508092020}

(Published online: September 2020)

Open Access

(C) International Ayurvedic Medical Journal, India 2020

Article Received: 27/08/2020 - Peer Reviewed: 08/09/2020 - Accepted for Publication: 08/09/2020

\section{Check for updates}

\section{ABSTRACT}

Background: Asrigdara is one of the most common Streeroga mentioned in which presents with the complaint of excessive bleeding per vaginum. It is caused due to the vitiation of Rasa dhatu, from which the Artava is formed. Considering the Nidanas of Asrigdara, it is clear that the Kapha Prakopaka Nidanas and Pitta Prakopaka Nidanas pave the way for Asrigdara. Considering the symptoms, Asrigdara can be correlated to dysfunctional uterine bleeding (DUB) which occurs commonly during the extremes of reproductive age.

Objectives: To compare the efficacy of Shatavarigopakanyadi Kashaya and Vasadi Kashaya in management of Asrigdara.

Materials and Methods: Randomized comparative clinical study of two groups consisting 20 patients in each group suffering from Asrigdara. Group A - Shatavarigopakanyadi Kashaya $50 \mathrm{ml}$ BD with Anupana of Sita and Madhu, Group B - Vasadi Kashaya $50 \mathrm{ml}$ BD with Anupana of Sita and Ghrita

Duration of Treatment: 2 consecutive cycles starting from $5^{\text {th }}$ day of menstruation in each cycle.

Results and Interpretation: Both the groups showed statistically significant results for all assessment criterias. Statistically there was no significant difference in curative effect between the groups. 
Conclusion: Both Shatavarigopakanyadi Kashaya and Vasadi Kashaya has statistically significant effect in Asrigdara.

Keywords: Asrigdara, Dysfunctional uterine bleeding, Shatavarigopakanyadi Kashaya, Vasadi Kashaya

\section{INTRODUCTION}

Motherhood is the most valuable gift from the Creator to the woman. Since ancient times, woman is most respected for this unique quality, without which her life is said to be incomplete. In the most famous epic, Ramayana, it is quoted that the mother who have given birth to you and the place where you were born is much greater than the abode of heaven. Woman have an important role in begetting a healthy progeny. Thus, the reproductive health of the woman should be given much importance since from her adolescent age. And menstruation is such a unique phenomenon in females which largely helps in determining the reproductive health of a woman. Changes in normal menstrual patterns of woman may adversely affect her physical and psychological wellbeing. Asrigdara is one such condition which generally refers to the excessive flow of menstrual blood. ${ }^{1}$ Acharya Sushruta has explained that when Artava flows out in more quantity or that occurs even apart from the regular menstrual cycle is to be understood as Asrigdara. ${ }^{2}$ It is also known as Pradara or Rakta yoni. Considering the symptoms, Asrigdara can be correlated to Dysfunctional Uterine Bleeding (DUB). DUB is defined as a state of abnormal bleeding without any clinically detectable organic, systemic and iatrogenic cause. The bleeding may be abnormal in frequency, amount or duration or combination of three. ${ }^{3}$ About $10-15 \%$ of women experience episodes of DUB sometimes during the reproductive years of their life and is common during the extremes of reproductive age. ${ }^{4}$ The highest incidence is seen in age group of 31 40 years $(32.8 \%)$ and it is common in parous women than in nulliparous women. ${ }^{5}$ The victimized patients end up with general debility and anaemia. ${ }^{6}$ In the present study, Shatavarigopakanyadi $\mathrm{Kashaya}^{7}$ and Vasadi Kashaya ${ }^{8}$ were taken due to the dominant properties of the drugs in it which are mainly Pitta Shamaka and Rakthasthambhaka. They not only offer an effective management, but these time-tested drugs may prove to be a safe alternative to modern day medicines for women suffering from Asrigdara.

Materials and Methods: This clinical study entitled "A comparative clinical study of Shatavarigopakanyadi Kashaya and Vasadi Kashaya in Asrigdara" was carried out in 40 Patients who were selected randomly from O.P.D. of Prasooti Tantra and Streeroga Department, Alva's Ayurveda Hospital, Moodbidri and other referrals.

\section{Source of data:}

a. Literary Source: All available Ayurvedic classical, Modern Medical literature, journals and websites about the disease and medicine were reviewed and documented for the planned study.

b. Sample Source: 40 patients attending Prasooti Tantra and Streeroga O.P.D of Alva's Ayurveda Medical College and Hospital, Moodbidri and other available sources.

c. Drug Source: Raw drug required for the preparation of Shatavarigopakanyadi Kashaya and Vasadi Kashaya was procured from local market and was identified and confirmed with the experts of Dravyaguna dept. and was prepared in accordance with the classical reference.

\section{Method of collection of data:}

1. A separate case proforma was prepared with details of history taking,physical signs and symptoms and necessary laboratory investigations and other investigations.

2. The parameters were scored on basis of gradation and was analyzed statistically.

Study design: A randomized comparative clinical study of two groups, consisting of 20 patients in each group.

\section{Diagnostic criteria:}

Patient fulfilling any two or more of the following criteria. 
1. Raja Atipravruthi (Excessive menstrual bleeding)

2. Deerghakalanubandhi (Prolonged menstrual bleeding)

3. Anruthavalpamapi (Intermenstrual bleeding)

4. Along with or without Angamarda (body ache) and Vedana (painful menstruation)

\section{Inclusion criteria:}

1. Patients fulfilling the diagnostic criteria

2. Patients with age group of $16-45$ years

3. Both married and unmarried women.

\section{Exclusion criteria:}

1. Bleeding from sites other than uterus.

2. Bleeding due to abortion.

3. Bleeding per vagina after menopause.

4. Patient with systemic and endocrine disorders interfering with the present study including:

HTN, DM, STD, Thyroid dysfunction, Bleeding disorders, PCOS etc.

5. Patients having $\mathrm{Hb}$ less than $8 \mathrm{gm} \%$.

6. Patients with IUCD and patients taking OCP.

7. Pelvic inflammatory disease, benign and malignant growth in the uterus.

Interventions: Group A: Group A was given Shatavarigopakanyadi Kashaya to take orally in the dose of $50 \mathrm{ml}$ twice daily before food with Sita and Madhu as Anupana for 2 consecutive menstrual cycles starting from $5^{\text {th }}$ day of menstruation in each cycle. Group B: Group B was given Vasadi Kashaya to take orally in the dose of $50 \mathrm{ml}$ twice daily before food with Sita and Ghrita as Anupana for 2 consecutive menstrual cycles starting from $5^{\text {th }}$ day of menstruation in each cycle.

Aassessment: Assessment was done once in every $15^{\text {th }}$ day for the treatment period of 2 consecutive menstrual cycles and follow up was done on $15^{\text {th }}$ day, $30^{\text {th }}$ day and $45^{\text {th }}$ day after the treatment period. separate case proforma was prepared with details of history taking, physical signs and symptoms and necessary laboratory investigations and other investigations. The parameters were scored on the basis of gradation and was analyzed statistically.

\section{Assessment criteria:}

\section{Subjective criteria}

- Intermenstrual Bleeding
- Body ache

- Pain during menstruation

Objective Criteria

- Duration of menstrual flow

- Amount of menstrual blood loss

Assessment of overall effect of therapy on the basis of percentage of relief obtained:

a. Marked Improvement: $76 \%-100 \%$ relief in the signs and symptoms

b. Moderate Improvement: $51 \%-75 \%$ relief in the signs and symptoms

c. Mild Improvement: $25 \%-50 \%$ relief in the signs and symptoms

d. No improvement: Below 25\% relief in the signs and symptoms

Assessment of total effect of therapy: Paired t-test was used for comparison within the group and unpaired t-test was used for comparison in between groups. The obtained data was analyzed statistically for the effect of both of the Kashayas which when conceded at the level of $p<0.001$ was taken as highly significant, $p<0.05$ or $p<0.01$ as significant effect and $\mathrm{p}>0.01$ as insignificant effect to carry out the results.

\section{DISCUSSION}

As per the statistical analysis there was no significant difference in the curative effect of Kashayas in both the groups and has significant effect in curing all the assessment criterias $(\mathrm{p}<0.001)$.

a) Effect in duration of bleeding: In Group $A$, the mean score which was 1.650 before the treatment was reduced to 0.500 after treatment. In Group B, the mean score which was 1.500 before the treatment was reduced to 0.600 after treatment. Statistically analyzing, it shows that there was only negligible difference in between the groups in reducing the duration of bleeding.

b) Effect in interval between menstrual bleeding: In Group A, the mean score which was 1.850 before the treatment was reduced to 0.700 after treatment. In Group B, the mean score which was 2.550 before the treatment was reduced to 0.945 after treatment. The increase in percentage of relief was comparatively high during all treatment periods in Group A while in 
Group B, it was only during second treatment period (DT 2), after which, only gradual relief was observed.

c)Amount of menstrual bleeding: In Group $A$ and Group B, the mean score was 1.300 and 1.700 respectively which reduced to 0.550 and 0.600 respectively after treatment. The increase in percentage of relief was comparatively greater in Group A during first treatment period (DT 1) and the relief was $36.3 \%$ after which only gradual relief was observed. In Group B, only gradual relief was observed during all treatment periods.

d)Effect on Vedana: In Group A and Group B, the mean score which was 0.800 and 0.750 respectively before the treatment reduced to 0.1000 and 0.150 respectively after treatment. The percentage of relief was greater in Group B during all treatment periods. But, comparatively, the relief was higher after treatment in Group A.

e) Effect on Angamarda: The mean score which was 0.700 in both the groups before the treatment reduced to 0.6 and 0.55 after treatment in Group A and Group $B$ respectively. The increase in percentage of relief was greater in Group A during treatment periods 1 and 2 (DT 1 and DT 2). But the percentage of relief was only gradually in Group B during all treatment periods.

Probable mode of action of Shatavarigopakanyadi Kashaya:

Shatavarigopakanyadi Kashaya predominantly possess Madhura, Tikta Rasas. Madhura Rasa have the property of Vata - Pitta Shamana which helps in controlling the amount of bleeding. It also does the Karma of Dhatu Poshana, Brimhana, Ojo Vardhana and Jeevana which all helps in curing the general debility caused by this disease and helps in maintaining the overall health of the woman. The Tikta Rasa is Kapha - Pitta Shamaka which along with Madhura Rasa helps in management of bleeding. Thus, the Madhura, Tikta Rasas helps in curing Asrigdara by maintaining the normalcy of all the Doshas that are involved in causing Asrigdara. Most of the drugs of the Kashaya possess Laghu, Ruksha Gunas. The Laghu Guna helps in Srotosodhana, thus helps in removing the Srotorodha caused by Kapha.
The Ruksha Guna helps in decreasing the Sara Guna and Drava Guna of Pitta which is increased in this disease and thus, helps in controlling the amount of bleeding efficiently. And a few drugs possess Guru Guna which helps in Brimhana of Deha which is also essential in management of Asrigdara. All the drugs have Sheeta Virya by which it acts as Raktapitta Shamaka and Raktha Sthambhaka which is the main action by which the disease Asrigdara is controlled. Most of the drugs possess Madhura Vipaka which helps in Pitta Shamana, which helps in maintaining the normalcy of Pitta. But a few drugs possess Katu Vipaka helps in relieving the symptoms by its Kaphahara properties which helps in removing the Srotorodha. Considering the Karma, drugs predominantly possess the properties of KaphaPittahara, Raktastambhaka, Vranasothahara, Balya. Shatavari, one among the drug in this Kashaya possessing these properties also act as Rasayani which helps in curing the disease in a better way including the general weakness caused by excessive bleeding. And Sariva is said to have the specific Karma of Pradara Nashana which also contribute for the cure of the disease. Also, the Anupanas, Sita and Madhu aids in curing the disease. Sita have the specific property of Raktapitta Shamana and Vatahara \& Madhu have the property of Asranut.

\section{Probable mode of action of Vasadi Kashaya:}

Both the Kashayas have Shatavari and Usheera in common. The drugs in this Kashaya too predominantly possess Madhura - Tikta Rasas which acts in the same way as of the Shatavarigopakanyadi Kashaya. Along with it, a few drugs possess Kashaya rasa which have Sangrahi property which helps in curing the amount of bleeding. Few drugs in the Kashaya possess Laghu - Ruksha Gunas and the other few drugs possess Guru - Snigdha Gunas equally. This indicates that the drugs help in curing bleeding by the Pitta Shamaka action and also helps in regaining the general health by Laghu - Ruksha Gunas and Guru - Snigdha Gunas respectively. All the drugs have Sheeta Virya which have Raktastambhaka action except Apamarga which have Ushna veerya which act as Vatahara and Kaphahara 
which helps in decreasing the symptom of Angamarda, Vedana and Srotororodha respectively. The drugs equally possess Katu and Madhura Vipaka. This helps in Pitta Shamana and at the same time, removing the Srotorodha caused by Kapha. The drug, Vasa which is considered as Agrya in Raktapitta present in this Kashaya plays a key role in curing the disease. The drugs in the Kashaya equally possess the qualities of both Vata-Pittahara and Kapha-pittahara which altogether helps in curing the Tridoshas involved in causing Asrigdara and thereby helps in managing the disease in a better way.

\section{CONCLUSION}

Asrigdara is the disease in which Vata and Pitta Prakopa is involved along with Srotorodha caused by Kapha Prakopa. The drugs administered in the study possess Vatahara, Pittahara and Kaphahara properties which helps in curing the disease. Considering the present study, the effect of both the Kashayas were statistically analysed, where both the groups attained a $\mathrm{p}$ value $<0.001$ when tested within the groups for all the parameters, which statistically have highly significant result. Between the groups, for all the parameters, the $p$ value was found to be $>0.05$ which is statistically insignificant which shows that both the Kashayas have only negligible difference in the effect of curing the disease. But the percentage of relief was found to be greater in patients of group $A$ than in group B. Also, it can be inferred that the difference in Anupanas have only negligible effect since there is only negligible difference in the effect of both the Kashayas while comparing in between the groups. Also, it was found that there was no further progress in patients during the follow up period in both the groups. Thus, it can be finally concluded that there is significant effect of both
Shatavarigopakanyadi Kashaya and Vasadi Kashaya in Asrigdara.

\section{REFERENCES}

1. Acharya Agnivesha, Caraka Samhita, Text with English Translation, Redacted by Dridhabala, Edited and Translated by Professor Priyavrata Sharma,Reprint Edition 2011, Chaukhamba Orientalia,Varanasi,Vol 2, Chikitsa Sthana, Chapter 30, Sloka No-209, P.522.

2. Acharya Susrutha, Susrutha Samhita (Text, English Translation, Notes, Appendeces and Index), Translated by Prof. K.R. Srikantha Murthy, Reprint Edition: 2012, Chaukhambha Orientalia, Vol 1, Sarira Sthana, Chapter-2, Sloka -18, P. 21.

3. D C Dutta, D C Dutta's Textbook of Gynecology including Contraception, Edited By Hiralal Konar, Published by Jaypee Brothers Medical Publishers(P) Ltd, Enlarged \& Revised Reprint of Sixth Edition, Chapter -14, P.187.

4. Shirish N Daftary, Shyam V Desai; Selected topics in Obstetrics and Gynaecology-1 for Postgraduates and Practitioners, Reprinted 2007, B.I. Publications Pvt Ltd, Chapter 17, P. 232.

5. Jadab K Pukhan, Gautom K Saharia, Rohini Goswami, Indian Journal of Medical Biochemistry, January-June 2016;20(1):11-15, Thyroid status in patients with dysfunctional uterine bleeding in a tertiary care hospital of Assam, http://www.jaypeejournals.com

6. Meenakshi Pal et al, Int. J. Research Ayurveda Pharm.7(1), Jan-Feb 2016, A clinical study to evaluate the effect of bolbaddha ras in Asrigdar, http://www.ijrap.net

7. K.V Krishnan Vaidyan, S Gopalapilla, Sahasrayogam Sujanapriya vyakhyanam, Ed. 31, Vidyarambham Publishers Mullakkal, Alappuzha-688011, Page no.-57

8. K.V Krishnan Vaidyan, S Gopalapilla, Sahasrayogam Sujanapriya vyakhyanam, Ed. 31, Vidyarambham Publishers Mullakkal, Alappuzha-688011, Page no.102

Table 1: Grading of duration of bleeding

\begin{tabular}{|l|l|l|}
\hline Days & Scoring & Grading \\
\hline$<8$ days & 0 & Normal \\
\hline $9-10$ days & 1 & Mild \\
\hline $11-12$ days & 2 & Moderate \\
\hline$>12$ days & 3 & Severe \\
\hline
\end{tabular}


Table 2: Grading of amount of blood loss

\begin{tabular}{|l|l|l|}
\hline No. of pads/day & Scoring & Grading \\
\hline 2 pads partially soaked & 0 & Nil \\
\hline 2-3 pads partially soaked & 1 & Mild \\
\hline $4-5$ pads partially soaked & 2 & Moderate \\
\hline$>6$ pads partially soaked & 3 & Severe \\
\hline
\end{tabular}

Table 3: Grading of interval between menstrual cycles

\begin{tabular}{|l|l|l|}
\hline No. of pads/day & Scoring & Grading \\
\hline$>30$ days & 0 & Nil \\
\hline $25-30$ days & 1 & Mild \\
\hline $20-24$ days & 2 & Moderate \\
\hline $15-19$ days & 3 & Severe \\
\hline$<15$ days & 4 & Very severe \\
\hline
\end{tabular}

Table 4: Grading of Angamarda and Vedana

\begin{tabular}{|l|l|}
\hline Scoring & Grading \\
\hline 0 & Absent \\
\hline 1 & Present \\
\hline
\end{tabular}

Table 5: Comparative results of Group A and Group B

\begin{tabular}{|l|l|l|l|l|l|l|l|}
\hline \multirow{2}{*}{ Parameters } & \multicolumn{2}{l|}{ BT-AT Mean } & \multirow{2}{*}{ D } & \multicolumn{2}{l|}{ \% of relief } & t value & P value \\
\cline { 2 - 7 } & Group A & Group B & & Group A & Group B & & \\
\hline Duration of menstrual bleeding & 1.15 & 0.9 & 0.250 & $72.73 \%$ & $61.3 \%$ & 1.751 & 0.096 \\
\hline Interval between menstrual bleeding & 1.15 & 1.5 & 0.050 & $72.98 \%$ & $62.75 \%$ & 0.326 & 0.748 \\
\hline Amount of menstrual bleeding & 1.1 & 1.1 & 0.100 & $66.66 \%$ & $64.71 \%$ & 0.698 & 0.494 \\
\hline Vedana & 0.7 & 0.6 & 0.050 & $87.5 \%$ & $80 \%$ & 0.438 & 0.666 \\
\hline Angamarda & 0.6 & 0.55 & 0.050 & $85.72 \%$ & $78.58 \%$ & 0.438 & 0.666 \\
\hline Total percentage of relief & & & & $77.11 \%$ & $69.5 \%$ & & \\
\hline
\end{tabular}

\section{Source of Support: Nil \\ Conflict of Interest: None Declared}

How to cite this URL: Priyanka Prem \& Kavitha B.K: A Comparative Clinical Study Of Shatavarigopakanyadi Kashaya And Vasadi Kashaya In Asrigdara. International Ayurvedic Medical Journal \{online\} 2020 \{cited September, 2020\} Available from: http://www.iamj.in/posts/images/upload/4391_4396.pdf 